\title{
"I HØJ GRAD ET SUBJEKTIVT VÆRK”
}

Anmeldelse af Den Danske Begrebsordbog. Redaktører: Sanni Nimb (hovedredaktør), Henrik Lorentzen, Liisa Theilgaard, Thomas Troelsgård. Det Danske Sprog- og Litteraturselskab, 2015. Udgivet i kommission på Syddansk Universitetsforlag (1397 sider).

\section{AF KIRSTEN MARIE ØVERAAS}

Med sine 1400 sider, 192.000 ord og udtryk og en vægt på over 3 kg er Den Danske Begrebsordbog en rigtig moppedreng. Eller måske skulle jeg sige en kæmpe, et monstrum, en klods, en kolos, en mastodont, en kleppert, en krabat, en sværvægter eller en dinosaurus? (Men jeg vil ikke kalde den et skrummel, for det er nedsættende, fortæller ordbogen mig.) Jeg kunne også udtrykke mig med adjektiver i stedet for substantiver og sige, at ordbogen er stor, omfattende, omfangsrig, vældig, mægtig, anseelig, velvoksen, granvoksen, diger og endda bamset. Og det er den i høj grad og i vid udstrækning, og så fik jeg også brugt nogle adverbier.

At jeg sådan kan variere min beskrivelse, ikke kun med forskellige ord, men også med forskellige ordklasser, er en af Den Danske Begrebsordbogs klare styrker.

\section{MERE END EN SYNONYMORDBOG}

Lad mig forst slå fast, at Den Danske Begrebsordbog ikke er en synonymordbog, selv om dens "nærmeste slægtning" er synonymordbogen, som det formuleres $i$ indledningen. Her forklares endvidere forskellen på de to slags ordbøger: Synonymordbøger angiver "ord der kan bruges som alternativer til opslagsordet når man skriver en sætning", mens begrebsordbøger også kan bruges til "at få et samlet overblik over ordforrådet indenfor et bestemt emneafgrænset felt", og også angiver "sø- 
skendebegreber", så der fx ved ordet "bold" ikke kun angives ord som "kugle" og "projektil", men også "vimpel" og "tøndebånd", fordi de har overbegrebet "gymnastikrekvisit" til fælles med ordet "bold". Der angives også ord, der er "mere løst knyttet til hinanden, for eksempel når bold nævnes sammen med genstande med tilnærmelsesvis samme form ("kugle", "cirkel", "boble", osv.)".

Ordbogen er bestemt heller ikke en betydningsordbog, som fx Den Danske Ordbog og Ordbog over det danske sprog. Slægtskabet med betydningsordbøgerne er endnu fjernere end med synonymordbøgerne, for slår man et ord op i en begrebsordbog, bliver man sandsynligvis mindre, ikke mere, sikker på, hvad ordets præcise betydning egentlig er. Men det er heller ikke formålet med at slå op i en begrebsordbog. Som det smukt beskrives i indledningen, er der "byttet om på kendt og ukendt: I betydningsordbogen er [opslags]ordet kendt og betydningen ukendt; i begrebsordbogen er betydningen kendt, mens betegnelserne for den er ukendte eller i hvert fald ikke fremme i bevidstheden." Den Danske Begrebsordbog er altså meget bredere og, om man så må sige, mere frit associerende, end de mere stringente eller begrænsede synonymordbøger og betydningsordbøger er.

\section{ORDBOGENS OPBYGNING}

Ordbogen består af to dele: en systematisk del og et indeks. Den systematiske del kan måske virke forvirrende, hvis man ikke før har brugt en begrebsordbog, for her står ordene ikke i alfabetisk rækkefølge, men er derimod ordnet $\mathrm{i}$ emneinddelte kapitler. Både håndgribelige emner som "Mad og drikke", "Sport og fritid" og "Samfund" og mere uhåndgribelige som "Liv", "Følelser" og "Sanseindtryk, tilstandsformer". Hvert kapitel er underinddelt i afsnit. Kapitel 1, "Natur og miljø", består således af "1.1 Universet", "1.2 Himmellegemer", "1.3 Jorden" osv. Heller ikke her er rækkefølgen altså alfabetisk, men følger en mere eller mindre intuitiv rækkefølge, som dog er angivet i en oversigt i starten. Hvert afsnit er yderligere underopdelt i ordklasser (og enkelte gange en "øvrige"-kategori, der kan indeholde talemåder og udråb). Inden for dem er der angivet nøgleord, som er fremhævet med fed og/eller kursiv, og ordene er inddelt i såkaldte betydningsgrupper, hvis 
start er markeret med en prik. Herefter er ordene ordnet efter, hvor generelle og/eller almindelige og/eller markerede ordene er, og der er også indsat kommentarer om "stilistisk afvigende ord", dvs. gammeldags, nedladende, uformelle ord osv.

Et eksempel er afsnittet "1.23 Ublandet" fra kapitel 1 ("Natur og miljø”), som er et af ordbogens absolut korteste. Det ser sådan ud:

$\mathrm{SB} \cdot$ renhed, homogenitet $\cdot$ rent guld, rent sølv $\cdot$ ren ilt, ren alkohol - ren bomuld, heluld, ren uld, helsilke · fuldblod, fuldblodshest, racehund, racekat · sortering, afgrænsning, udskilning, rensning, udrensning, udvaskning, rendyrkning

VB · sortere, udskille, afgrænse, skille, skille ud, rense, rendyrke, destillere, abstrahere, si, sigte fra, udvaske, si fra, sortere fra, frasortere

ADJ · ublandet, ren · fin, gedigen, lødig, pur, rendyrket, straight, udelt idel, genuin, homogen · ren og skær, lutter, $100 \%$, hel-, blot og bar, uforfalsket, ægte $\cdot$ raceren, ægte, ren fuldblods

ADV $\cdot$ kun, udelukkende, alene

Som det fremgår, er der mange forskellige niveauer og markeringer involveret $\mathrm{i}$ ordbogens systematiske del, og denne anmelder har svært ved helt at gennemskue, og dermed anvende, markeringerne, især hvornår ord er skrevet med kursiv og fed, og hvornår de ikke er. Men som bruger anvender man næppe aktivt ordenes rækkefølge til fx at finde det mest eller mindst markerede ord af de angivne, og netop fordi ordene ikke bare er oplistet, men så grundigt annoteret, er det nemt at finde netop det ord, man leder efter, eller at overskue, hvilke ord man kan vælge imellem. Dertil kommer, at der i starten af hvert afsnit bliver henvist bredt på tværs af ordbogen til andre, beslægtede kapitler og afsnit, så der fx i starten af "1.23 Ublandet" bliver henvist til både "4.34 En", "9.51 Kvalitet", og "13.15 Metaller". Også her er afsnittet"1.23 Ublandet" kortfattet i forhold til andre afsnit, som snildt kan have henvisninger til ti eller flere kapitler og afsnit. Både henvisningerne og ordbogen i det hele taget spænder altså vidt. 
Ordbogens anden del, indekset, er den, man bruger, hvis man bruger ordbogen som en slags udvidet synonymordbog. Her er alle ordbogens ord (undtagen, ifølge indledningen, cirka en fjerdedel af flerordsudtrykkene af pladshensyn) oplistet alfabetisk, og ved hvert ord er der angivet, hvor i den systematiske del ordet kan slås op. Indekset fungerer således som en nøgle til den systematiske del. Hvis man bruger ordbogen til at finde synonymer eller beslægtede ord, starter man derfor med at slå et ord op i indekset og bliver så derfra ledt til det sted i den systematiske del, hvor man kan finde det eller de ord, man leder efter. Et vigtigt skridt på vejen er, at der $\mathrm{i}$ indekset ofte er angivet flere end én henvisning til den systematiske del. Slår man fx ordet "renhed" op, bliver man henvist til "renhed 1.23 SB", som vi så ovenfor, men også til "okosystem 1.20 SB", "personlig bygiejne 2.27 SB", "renbed 9.57 SB", "ansvarsfolelse $10.50 \mathrm{SB}$ ", "klang 14.11 SB" og "uskyld 15.32 SB".

Ordbogen rummer også en indledning, som ud over en interessant introduktion til bogens tilblivelse og begrebsordbøgers historie giver en vejledning i brugen af bogen. Men det skal siges til ordbogens ros, at den sagtens kan bruges, uden at man først terper indledningen. Har man blot forstået den grundliggende opbygning og samspillet mellem de to dele, kan man sagtens gå i gang med at bruge den. Det skyldes ikke mindst ordbogens layout og typografi. Fra siden kan man se ordbogens kapitel- og bogstavinddeling, og opslagene er markeret med brug af fed, kursiv og versaler, som det kan ses i eksemplet "1.23 Ublandet" ovenfor. Ordbogen og de enkelte kapitler og afsnit er lette at orientere sig i og danne sig et overblik over.

Ordbogen kan altså bruges både med udgangspunkt i den systematiske del og $\mathrm{i}$ indekset. Hvor man starter, afhænger af formålet med opslaget. Starter man med at slå op i indekset, og det omtales i indledningen som ordbogens "primære brug", kan man bruge ordbogen som en slags udvidet synonymordbog: "Jeg har ordet lige på tungen, det er ikke helt "renhed", men deromkring!" eller 'Nu har jeg brugt "renhed" to gange i denne sætning; jeg må variere mit sprog!". Den anden måde, hvor man starter i den systematiske del, må nærmere have karakter af hyggelæsning, måske for at udvide sit ordforråd eller for simpelthen at glæde sig over sprogets afkroge. Ordbogen giver i meget højere grad end både en betydningsordbog og en synonymordbog et overblik over 
hele sproget, og selv om resultatet er omfangsrigt og måske overvældende, er den yderst brugbar, når man har brug for at lede efter et ord $i$ en ikke nærmere defineret omegn af et andet ord. Og det har man - eller det bør man have - hvis man skal udtrykke sig varieret og/eller præcist.

\section{HJELP TIL HURTIGE, HURTIGE DYR}

Det er netop sådan, jeg selv bruger Den Danske Begrebsordbog i mit virke som oversætter. Ikke som betydningsordbog eller synonymordbog, men som et værktøj til at variere og præcisere mit sprog. Jeg skulle fx for nylig oversætte denne beskrivelse af nogle dyr: "Cunning, fast predators and skittish, speedy prey." Her var mit problem ordene "fast" og "speedy". Fordi de begge to svarer ret godt til ordet "hurtige" på dansk, kunne jeg ende med den alt for ensformige oversættelse: "Snu, hurtige rovdyr og urolige, hurtige byttedyr". Nu kunne jeg selvfølgelig slå op i en synonymordbog og finde et andet ord for "hurtig", fx "hastig", "rap", "snar" eller "væver", som Dansk Synonymordbog bl.a. foreslår. Men hvis jeg gør det, begrænser jeg mig til at holde mig inden for den samme sætningsstruktur i min oversættelse, som originalteksten har, og erstatte det engelske adjektiv med et adjektiv på dansk. Og det er der egentlig ikke nogen grund til, i hvert fald ikke i den type oversættelse jeg bedriver, hvor mundtlighed og letlæselighed er langt vigtigere end minutiøs korrekthed (i modsætning til inden for $\mathrm{fx}$ merkantil oversættelse).

Ordbogens indeks sender mig fra ordet "hurtig" i retning af 11 forskellige opslag, hvor ordet er ordnet sammen med andre beslægtede ord. Og her kommer vi til styrken, jeg nævnte i starten af denne anmeldelse: Hvis jeg flytter mit blik en anelse op eller ned, bare inden for afsnittet "10.19 Livlighed, foretagsomhed", får jeg forslag som "iver", "gang i løjerne", "energibombe", "være i fuld vigør", "gnistre", "på livet løs", "tjuhej" og "hellere lille og vågen end stor og doven", ud over selvfølgelig adjektiver som "gesvindt", "snar", "kvik", "vaks" osv. Mange af disse forslag er ikke anvendelige i netop dette tilfælde, og sådan må det nødvendigvis være, når de spænder så vidt og er så mangfoldige. Men her får jeg altså muligheden for at omformulere min 
sætning "Snu, hurtige rovdyr og urolige, hurtige byttedyr" til fx "Snu rovdyr, der gnistrer af fart, og urolige byttedyr i fuldt vigør". Om jeg ender med den løsning, afhænger naturligvis af, om det er den bedste i netop den kontekst, oversættelsen skal indgå i, men det er en ganske anden diskussion. Vigtigt her er, at Den Danske Begrebsordbogs omfang og overskuelighed giver mig mulighed for at arbejde mere kreativt med en tekst, end andre ordbøger gør.

Det kommer mig også til gavn i de mange situationer, hvor jeg "har ordet på tungen”. Når man oversætter, oplever man gang på gang, at man slår et ord op i en ordbog og får angivet det tilsvarende ord på dansk, men ved eller fornemmer, at ordet på fremmedsproget ikke svarer fuldstændigt til det angivne. Der ligger måske en anden betydningsnuance eller sprogtone i det, som ikke ligger i ordbogens oversættelse. Her vil løsningen ofte være at omformulere, og altså udtrykke det samme i oversættelsen, som ordet på fremmedsproget gør, men ved hjælp af flere ord end ét, eller med ord fra en anden ordklasse. Og her er det igen en fordel at kunne flytte blikket mellem de forskellige ordklasser inden for et opslag og blive inspireret til andre formuleringer, der kan gengive betydningen bedst.

Ordbogen kan altså hjælpe sin bruger til at komme ud over sit eget ordforråd og endda genoverveje, hvordan en hel sætning overhovedet skal formuleres. Det er et værdifuldt værktøj for alle, der skal formulere sig, uanset om det er i form af oversættelser eller egne tekster.

\section{EN ANALOG ORDBOG I EN DIGITAL VERDEN}

Den Danske Begrebsordbog er, som nævnt, en moppedreng, og selv om de $3 \mathrm{~kg}$ ligger stabilt på skrivebordet, kommer de altså ikke med i min håndtaske, hvis jeg skal arbejde andre steder fra. Det virker temmelig gammeldags at lancere - og at købe - en analog, fysisk ordbog i dag, og det harmonerer dårligt med, at en meget stor del af de andre gængse ordbøger findes online. I mit daglige arbejde bruger jeg Sproget.dk, som fungerer som indgang til Retskrivningsordbogen, Den Danske Ordbog, Dansk Synonymordbog m.fl., samt flere forskellige flersprogede ordbøger, enten i deres online udgave, såsom Gyldendals Store Rode Ordboger, eller nogle, som simpelthen kun findes online, såsom Sprogbro.org og Ord- 
bogen.com. Kun mere specialiserede ordbøger og opslagsværker bruger jeg på fysisk form, simpelthen fordi materialet ikke findes online. Og så altså Den Danske Begrebsordbog.

På Det Danske Sprog- og Litteraturselskabs hjemmeside (https:// dsl.dk/sprog/ordboger-og-sprogteknologi/dansk-tesaurus-begrebsordbog-over-moderne-dansk) kan man da også læse, at der er planlagt en "netpublikation". Herom står der, at "den digitale udgave planlægges lanceret gradvis, dels ved at den begrebsmæssige komponent $i$ DDO udvikles med data fra begrebsordbogen, dels - afhængigt af bevillingssituationen - som en selvstændig ordbogsudgivelse." Det fremgår ikke, hvad status er, men det vil sikkert være interessant for mange.

Når det er sagt, holder jeg meget af, at ordbogen er fysisk og af papir. Måske fordi det understøtter den frie, undersøgende bladring på en måde, som et online opslagsværk typisk ikke gør. Og de mange henvisninger i starten af afsnittene til andre, beslægtede afsnit fungerer præcis som hyperlinks i teksten - bortset fra at man fysisk skal bladre hen til dem, ikke klikke sig hen til dem. Jeg kunne være bange for, at en digital version af Den Danske Begrebsordbog ville miste den spontanitet, hvormed man kan udforske de mange beslægtede ord, og som jo netop er det, der adskiller den fra betydnings- og synonymordbøgerne. Jeg håber, at en eventuel digitalisering tager højde for det, så man stadig kan bevæge sig mere eller mindre planløst rundt i opslagene og lade sit øje fange af et ord, man aldrig ville have fundet på at slå op. Måske er løsningen simpelthen en pdf-version af den fysiske ordbog, blot med hyperlinks $i$ indekset og afsnitshenvisningerne.

\section{SUBJEKTIV SPROGBRUG PÅ BOGFORM}

Som det er fremgået, er Den Danske Begrebsordbog forbundet på kryds og tværs af et stort antal henvisninger, og ordene er ikke kun ordnet efter ordklasser, men også efter både betydninger og hvor almindelige eller generelle eller markerede ordene er. I ordbogens systematiske del er ordene altså ikke alfabetiseret, men ordnet ud fra redaktionens vurderinger af det enkelte ords betydning, brug og beslægtethed med andre ord. Det, at ordene er ordnet ud fra redaktionens vurdering, beskrives 
$\mathrm{i}$ indledningen som at "en begrebsordbog er i høj grad et subjektivt værk".

Subjektivitet er nok ikke noget, vi plejer at forbinde med ordbøger og opslagsværker, men det burde det selvfølgelig være, ikke mindst når det drejer sig om en så bredspektret ordbog som denne. For sprog bruges jo forskelligt fra sprogbruger til sprogbruger og fra kontekst til kontekst. I én tekst er byttedyret i fuldt vigør, og i en anden er det ganske simpelt hurtigt, og hvis en anden sprogbruger formulerer teksten, gør dyret noget helt tredje. Sprogbrug er i sit udgangspunkt subjektivt, og det afspejles i, at Den Danske Begrebsordbog er så omfangsrig og mangefacetteret, som den er. Det er da smukt.

Kirsten Marie Øveraas

Oversætter og forfatter

km@kirstenmarie.dk 